\title{
The Genus Auricularia Bull. ex Juss. (Basidiomycota) in Cerrado (Brazilian Savanna) areas of Goiás state and the Federal District, Brazil
}

\author{
Alvarenga RLM ${ }^{1,2}$, Naves $\operatorname{LRR}^{1,3}$ and Xavier-Santos $\mathrm{S}^{1,2}$ \\ ${ }^{1}$ Universidade Estadual de Goiás, Campus de Ciências Exatas e Tecnológicas, Laboratório de Biodiversidade do \\ Cerrado (UEG/CCET/LABBIC), BR 153, Km 98, $n^{\circ}$ 3105, CEP 75132-903, Anápolis, Goiás, Brazil \\ ${ }^{2}$ Programa de Pós-Graduação em Recursos Naturais do Cerrado (RENAC)/UEG/CCET \\ ${ }^{3}$ Universidade Federal de Goiás, Instituto de Ciências Biológicas, Laboratório de Ficologia (LAFIC), Av. Esperança, \\ Setor Itatiaia, CEP 74690-900, Goiânia, Goiás, Brazil
}

Alvarenga RLM, Naves LRR, Xavier-Santos S. 2015 - The Genus Auricularia Bull. ex Juss. (Basidiomycota) in Cerrado (Brazilian Savanna) areas of Goiás state and the Federal District, Brazil. Mycosphere 6(5), 532-541, Doi 10.5943/mycosphere/6/5/3

\begin{abstract}
The present study reports species occurrence of the genus Auricularia found in areas of the Cerrado biome in Goiás state and in the Federal District, thereby expanding the occurrence records of this species in Brazil. A total of 101 samples were found, they are distributed into four species: A. delicata, A. fuscosuccinea, A. mesenterica and A. nigricans; the first three are being recorded for the first time for Goiás state and A. delicata are being registered for the first time for the Federal District.
\end{abstract}

Keywords - Auriculariales - Central Brazil - jelly fungi

\section{Introduction}

The genus Auricularia, belonging to the family Auriculariaceae, was established by Bulliard in 1787. The basidioma is gelatinous when fresh, pileate, auriform to orbiculate, substipitate or stipitate, resupinate, lobed, often upturned and color ranging from white to brownish (Bulliard 1787). It distinguishes itself macroscopically from other genera of the family by a basidioma with a zone of internal hyphae, hymenial surface ranging from smooth to reticulate, and microscopically by its dense hymenial surface with basidia ranging from cylindrical to clavate, with three septations and basidiospore white to ochraceous, able to produce conidia (Bulliard 1787, Lowy 1952, 1971).

Twenty-eight species are considered valid (Kirk 2015), often found in tropical, subtropical and temperate zones. Lowy (1951) developed a classification system based on identifying zones in the basidioma, which are observed after cross-sectioning, a technique still used as the primary taxonomic method for the genus, as observed in studies by Lowy (1952, 1971), Batista et al. (1966), Góes-Neto (1996), Sobestiansky (2005), and Looney et al. (2013).

The occurrence of species from the genus has been recorded in Brazil (Trierveiler-Pereira et al. 2009; Gibertoni \& Drechsler-Santos 2010; Abrahão et al. 2012; Dreschsler-Santos et al. 2013; Alvarenga \& Xavier-Santos, 2015), mainly those most easily recognizable, collected sporadically along with other groups of macromycetes. The present study reports the occurrence of Auricularia 
species collected in areas of the Cerrado biome in Goiás state and the Federal District, expanding the occurrence records of these species in Brazil.

\section{Materials \& Methods}

The specimens studied were collected over the last 14 years (2001-2014) in different locations in Goiás state and in an area of the Federal District: Goiás, City of Anápolis, Campus of the Universidade Estadual de Goiás, Trilha do Tatu Ecological Reserve (16 23'40''S and 48 57'32'’O) and Ciliar Forest of Ribeirão das Antas, AmBev, Cebrasa Branch (16 $17^{\prime}$ '56.34'S and 48 48'43.68'O); City of Goiânia, Campus II of the Universidade Federal de Goiás, Auguste SaintHilaire Forest (BASH) (16 36'26.74' 'S and 49 $15^{\prime}$ '51.69' O); City of Caldas Novas, Serra de

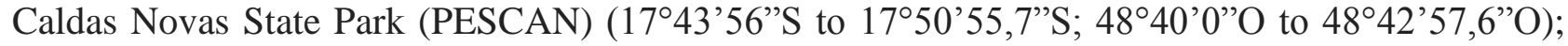

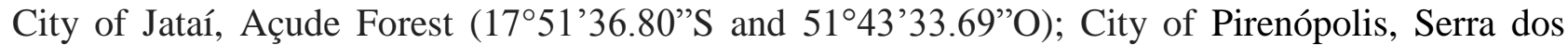

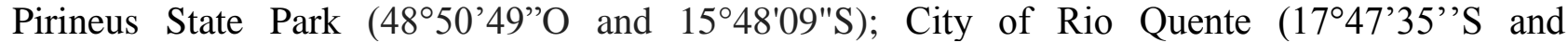
4847'36' 'W); City of Silvânia, Silvânia Forest Park (FLONA) (16³8'30.46"S and 48³9'3.11'”) and the Federal District, City of Brasília: Botanical Garden of Brasília $\left(15^{\circ} 52^{\prime} 21^{\prime \prime} \mathrm{S}\right.$ and 47 50'50"O) (Fig. 1). All the locations are situated in the Central Plateau of Brazil and belonging to Cerrado biome, characterized by different phytophysiognomies, including mesophyll forest, semi deciduous, ciliary and gallery forest, that were sampled in this study.

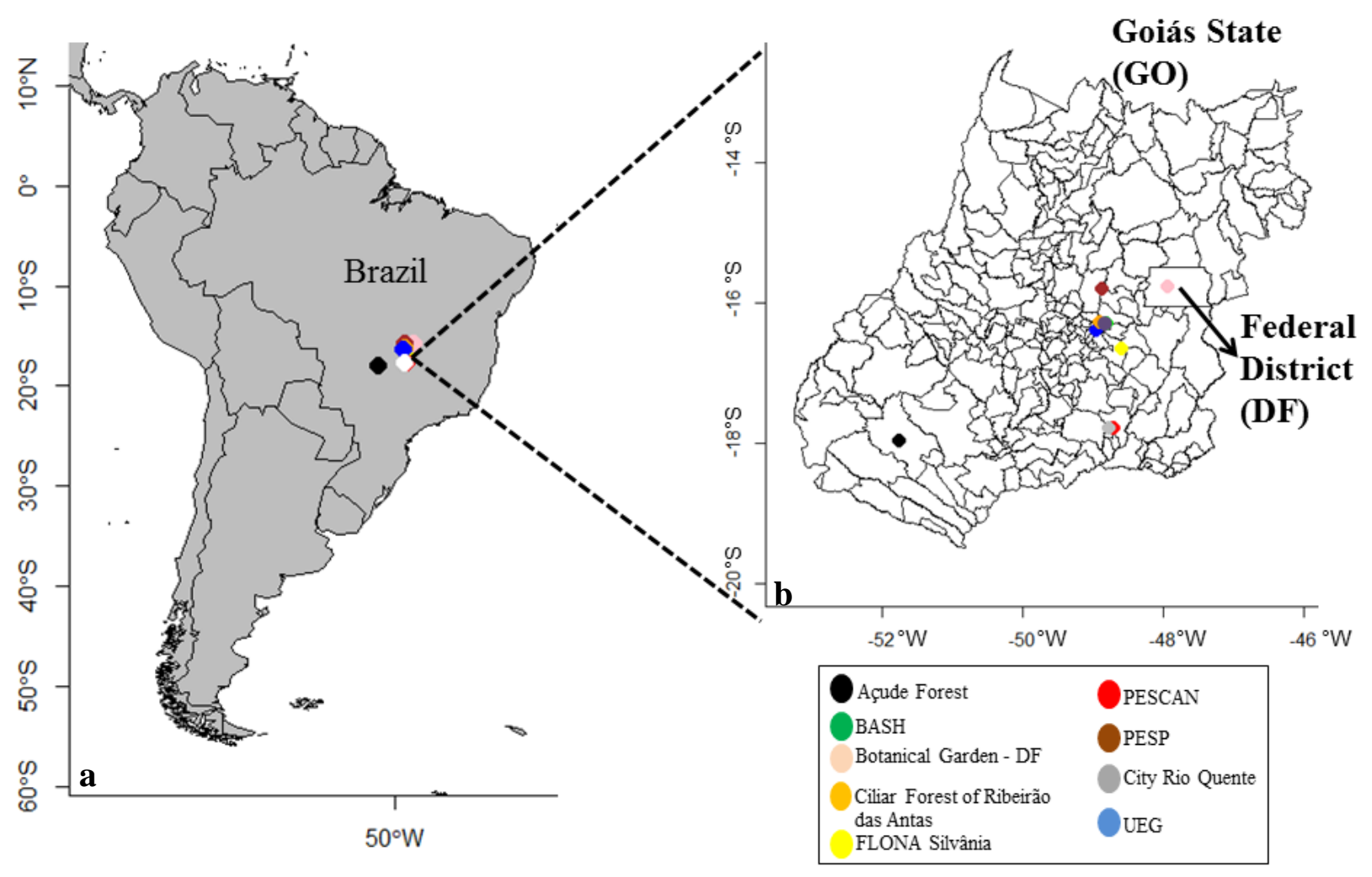

Fig. 1 - a Map of South America, showing collections areas in Brazil. b Location of collection areas in Goiás state and Federal District. Maps produced with R Software R (2015). (BASH Auguste Saint-Hilaire Forest; FLONA Silvânia - National Forest of Silvânia; PESCAN - Serra de Caldas Novas State Park; PESP - Serra dos Pireneus State Park and UEG - Trilha do Tatu Ecological Reserve).

For the taxonomic study, macro and microscopical features were analyzed, including the general aspect of the basidioma, hymenial surface and zones of internal hyphae according to Lowy $(1952,1971)$ and Looney et al. (2013). The basidiomata underwent dry and wet preservation and were deposited at the Herbarium of Universidade Estadual de Goiás (HUEG). 
Species occurrence is distributed by Brazilian states, which are represented by acronyms: Acre (AC); Alagoas (AL); Amazonas (AM); Amapá (AP); Bahia (BA); Ceará (CE); Federal District (DF); Espirito Santo (ES); Goiás (GO); Maranhão (MA); Minas Gerais (MG); Mato Grosso (MT); Mato Grosso do Sul (MS); Pará (PA); Paraíba (PB); Pernambuco (PE); Piauí (PI); Paraná (PR); Rio de Janeio (RJ); Rio Grande do Norte (RN); Rondonia (RO); Rio Grande do Sul (RS); Roraima (RR); Santa Catarina (SC); Sergipe (SE); São Paulo (SP) and Tocantins (TO).

\section{Results \& Discussion}

A total of 101 samples of the genus Auricularia were examined, they were distributed into four species: A. nigricans (the most frequent species, with $54 \%$ of occurrences), A. fuscosuccinea (20\%), A. mesenterica (13\%) and A. delicata sensu lato (12\%). None of the species showed substrate specificity, occurring in both live wood or in decomposition. These are the first records of A. fuscosuccinea, A. mesenterica and A. delicata for Goiás state and of A. delicata for the Federal District.

\section{Taxonomy}

Auricularia delicata (Mont. ex Fr.) Henn. lato sensu

Description - Basidioma yellowish brown when mature and dry, pinkish when fresh or when preserved in wet way; $1.0-8.0 \mathrm{~cm}$ long and $1.5-5.0 \mathrm{~cm}$ wide. Abhymenium with yellowish hairs are gregarious but not dense, only on the small stipe, with sudden thickening at the base. Margin smooth, when young and undulated or lobad, when adult. Medulla absent, even in thick cuts, hyaline, branched and septates hyphae $(2.5-5.0 \mu \mathrm{m})$. Zona pilosa 50-70 $\mu \mathrm{m}$, zona compacta superioris $15-25 \mu \mathrm{m}$, zona subcompacta superioris is 36-48 $\mu \mathrm{m}$, zona laxa intermedia $300-450$ $\mu \mathrm{m}$, zona subcompacta inferioris $120-140 \mu \mathrm{m}$, hymenium 76-90 $\mu \mathrm{m}$ with the same color as the abhymenial surface, reticulate, alveolate. Basidia cylindrical, spindle-shaped, 30-50 $\mu \mathrm{m} \times 4-5 \mu \mathrm{m}$, basidiospores allantoid to curved-cylindrical, hyaline, generally with guttulate, (9)10-13(15) $\mu \mathrm{m} \times$ (3.5)4-5(6) $\mu \mathrm{m}$.

Distribution - Cosmopolitan, In Brazil: states of AM, BA, MT, RO, SC, SP, PA, PR.

Material examined - BRAZIL, Federal District, City of Brasília: Botanical Garden of Brasília, 01/12/2010. Alvarenga, R.L.M. (24)-HUEG 8387: The basidioma this sample was colonized by myxomycetes plasmodium the Physarum polycephalum; Goiás: City of Anápolis, Campus of the Universidade Estadual de Goiás, Trilha do Tatu Ecological Reserve, 04/10/2010, Alvarenga, R.L.M. (04)-HUEG 8469; 12/11/2007, idem Faria, J.E.Q. \& Moreira, I.C. (229)-HUEG 8451; idem 28/09/2009 Xavier-Santos, S. (4306)-HUEG 8455; idem 10/12/2010 Xavier-Santos, S. (4500)-HUEG 8457; City of Caldas Novas, 02/11/2007, Xavier-Santos, S. (2137)-HUEG 8399; City of Goiânia, Campus II of the Universidade Federal de Goiás, Auguste Saint-Hilaire Forest (BASH), 07/10/2013, Naves, L.R. (11)-HUEG 10109, idem 16/01/2014, Naves, L.R. (92)-HUEG 10110 and idem, 22/02/2014, Naves, L.R. (158)-HUEG 10111; City of Silvânia, Silvânia Forest Park (FLONA), 22/10/2010, Alvarenga, R.L.M. (12)-HUEG 8475; idem (14)-HUEG 8479; idem (15)-HUEG 8483.

Notes - Specimens were collected from live trunks or in decomposition, mainly in wet areas. The species distinguishes itself from other species of the genus primarily by reticulate hymenial surface and from Auricularia subglabra Looney, Birkebak, \& Matheny because it lack medulla and presence of gregarious hairs. In recent molecular analyses, Looney et al. (2013) observed the formation of two clades: A. delicata clado I, A. delicata clado II. Considering the impossibility of this molecular analysis in the present material, the species is being referred as Auricularia delicata lato sensu. One of the specimens examined was found to be a substrate for the myxomycetes plasmodium Physarum polycephalum. The species is used as food by the Uitoto, Muiana and Andoke indigenous communities in Colombia (Vasco-Palacios et al. 2008). These are the first records of species occurrence for Goiás state and the Federal District. 

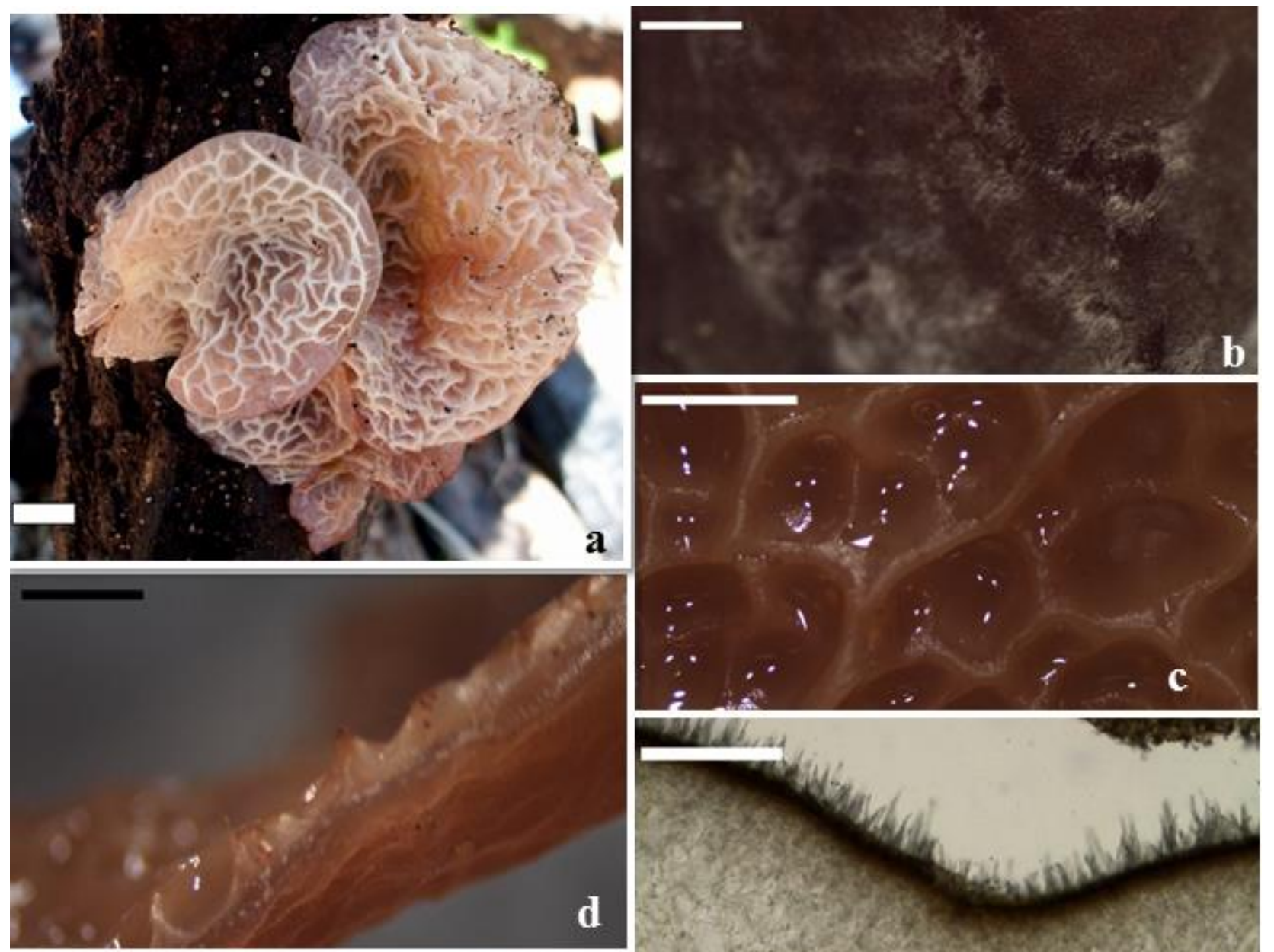

d
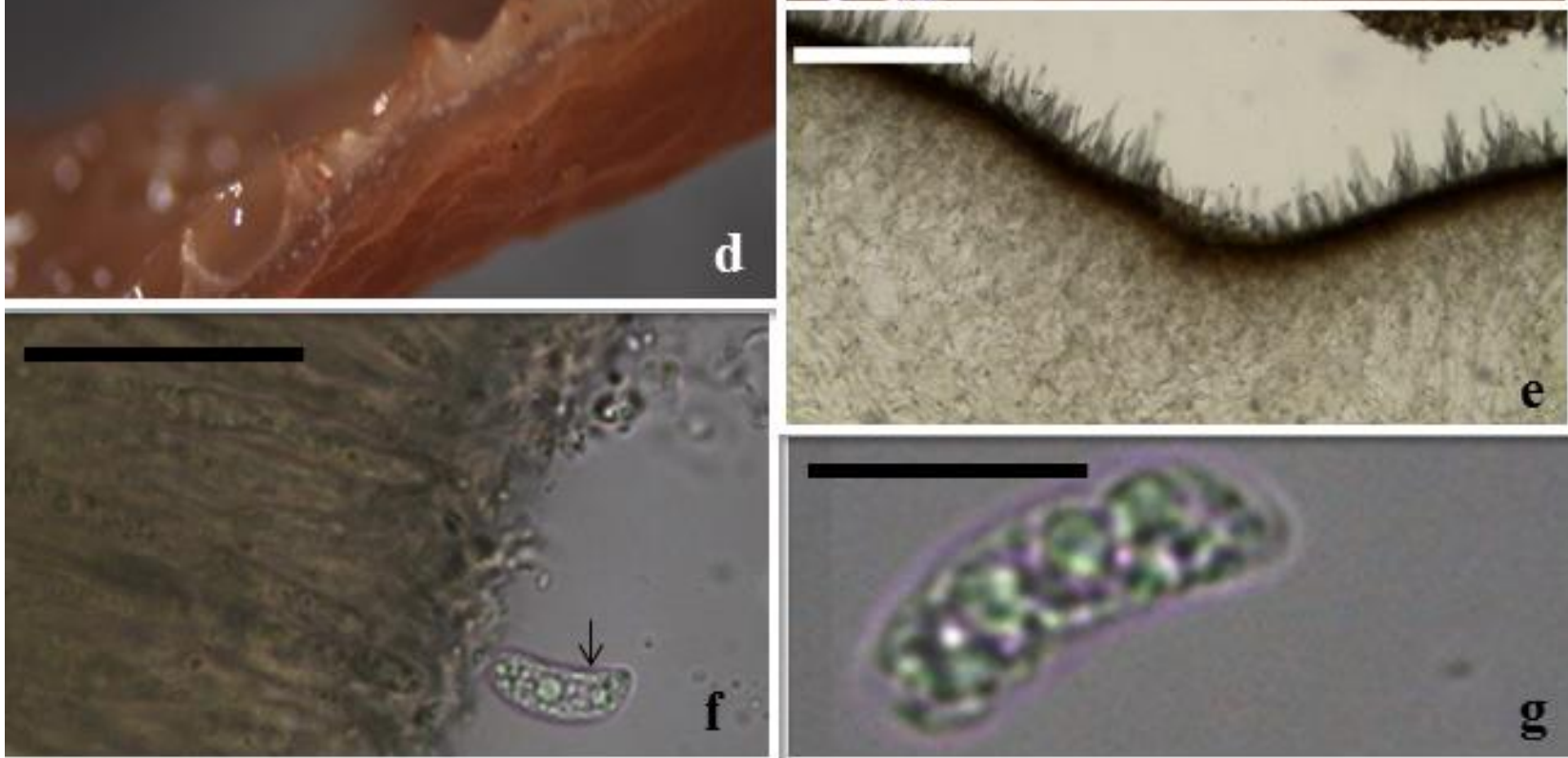

Fig. 2 - Auricularia delicata. a-Basidiomata on the substrate; b-Pilous abhymenial surface of the dehydrated basidioma; c-Hymenial surface of rehydrated basidioma; d-Cross-section of basidioma; e-Cross-section of the pilous region; f-Hymenial layer with basidiospore (arrow); g-Basidiospore with oil droplet inside. Scale bars- a: $2 \mathrm{~cm}$; b-d: $2 \mathrm{~mm}$; c-e: $0.5 \mathrm{~mm}$; f-g: $20 \mu \mathrm{m}$.

Auricularia fuscosuccinea (Mont.) Henn.

Fig 3

Description - Basidioma ranging between 3-10 cm long and 4-13 cm wide, pileate and cupulate, gelatinous, soft to the touch when fresh becoming very horny, rigid and brittle when dry. Abhymenial surface slightly pilous with gregarious hairs, color brown to reddish when fresh, becoming darker when dried. Margin commonly reflexed, medulla present. Hyaline hyphae, branched and septate $(1.5-3.6 \mu \mathrm{m})$. Zona pilosa 40-100 $\mu \mathrm{m}$, zona compacta 18-47 $\mu \mathrm{m}$, zona subcompacta superioris $25-59 \mu \mathrm{m}$, zona laxa superioris $80-300 \mu \mathrm{m}$, medulla 50-230 $\mu \mathrm{m}$, zona laxa inferioris 30-389 $\mu \mathrm{m}$, zona subcompacta inferioris $50-170 \mu \mathrm{m}$, hymenium 36-73 $\mu \mathrm{m}$. Basidia elongated 48-65 × 5-7 $\mu \mathrm{m}$, basidiospores (5)9-10.3(13) $\times(4) 4.5-5(5.6) \mu \mathrm{m}$, curved-cylindrical. Basidia and basidiospores with guttulate. 

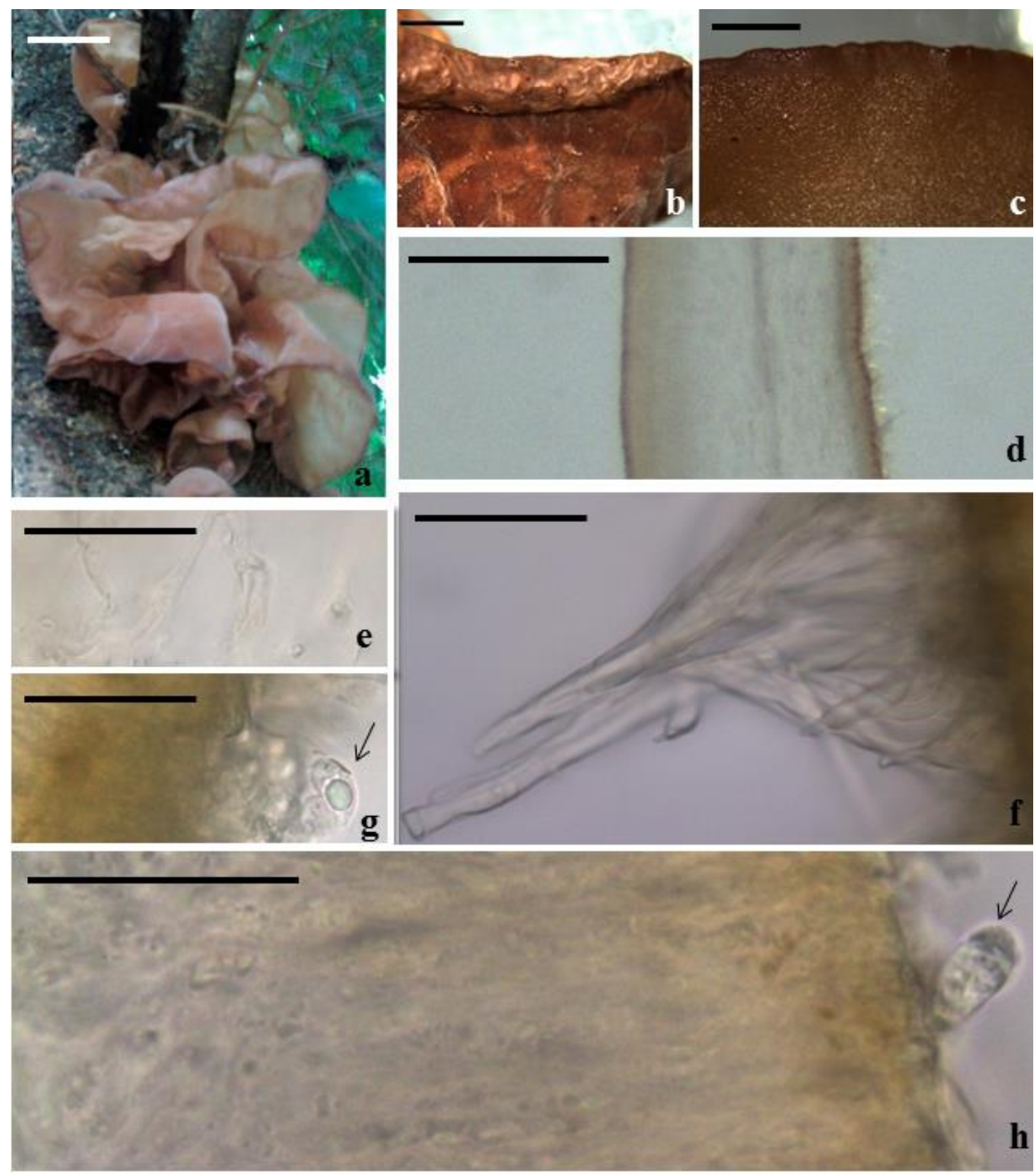

Fig. 3 - Auricularia fuscosuccinea. a-Basidiomata on the substrate; b-Revolute margin of the dehydrated basidioma; c-Margin of the abhymenial surface of the basidioma preserved by wet way; d-Cross-section; e-Hyphae of the medulla immersed in mucilage; f-Abhymenial hairs; g-Hymenial layer with basidiospore (arrow); h-Basidiospore with oil droplets inside (arrow). Scale bars-a: $1 \mathrm{~cm}$; b-c: $2 \mathrm{~mm}$; d: $0.5 \mathrm{~mm}$; e-h: $20 \mu \mathrm{m}$.

Distribution - Pantropical, In Brazil: States of AM, MT, RJ, RO, RS, SC, SP, PA, PR.

Material examined - BRAZIL, Goiás State, City of Anápolis, Campus of the Universidade Estadual de Goiás, Trilha do Tatu Ecological Reserve, 28/09/2009 Xavier-Santos, S. (4307)-HUEG 8471; idem 10/12/2010 Xavier-Santos, S. (4507)-HUEG 8458; idem 04/10/2010 Alvarenga, R.L.M. (06)-HUEG 8477; idem 2001 Xavier-Santos, S. (3011)-HUEG 8388, idem (3027)-HUEG 8376, idem (3042)-HUEG 8392, idem 10/02/2009 Xavier-Santos, S. (4147)-HUEG 8473; City of

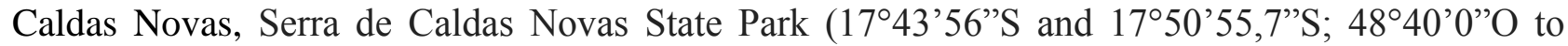
4842'57,6”'O), 23/11/2008, Xavier-Santos, S. (3313)-HUEG 8468; City of Goiânia, Campus II of the Universidade Federal de Goiás, Auguste Saint-Hilaire Forest (BASH), 05/12/2013 Naves, L.R.R. (45)-HUEG 10116; idem 05/12/2013 Naves, L.R.R. (49)-HUEG 10117; idem 16/01/2014 
Naves, L.R.R. (97)-HUEG 10115; idem 22/02/2014 Naves, L.R.R. (128)-HUEG 10112; idem 29/03/2014, Naves, L.R.R. (223)-HUEG 10113; idem 03/05/2014 Naves, L.R.R. (284)-HUEG 10114; City of Jataí, Açude Forest, 09/02/2011 Alvarenga, R.L.M. (63)-HUEG 8377; City of Rio

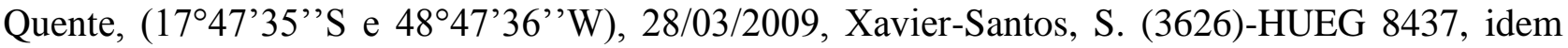
(3629)-HUEG 8440; City of Silvânia, Silvânia Forest Park (FLONA), 22/10/2010 Alvarenga, R.L.M. (16)-HUEG 8478; idem 26/06/2009 Xavier-Santos, S.(3851)-HUEG 8467, idem (3961)HUEG 8406.

Notes - Collected from live trunks or trunks in decomposition, with or without exposure to direct sunlight. A. fuscosuccinea differs from other species of the genus by having basidiomata vinaceous brown to rosy brown and clear medullary zone. Fidalgo \& Hirata (1979) reported the use of this species as food by Txição and Tucarramãe indigenous people in Brazil. In some of the samples collected, it was observed that the basidioma serves as an egg-laying site and food during the larval development of flies from the genus Drosophila spp..These are the first reports of species occurrence for Goiás state.

Auricularia mesenterica (Dicks.) Pers.

Fig. 4

Description - Basidioma gelatinous when fresh, 8-13 cm long, resupinate with marginal ruptures. Abhymenial surface with greyish brown hairs in dense tufts, grey hymenium when young and dark purple when mature. Margin corrugated. Medulla absent. Hyaline hyphae, branched and septate $(1.6-3 \mu \mathrm{m})$ in the zona laxa intermedia. Zona pilosa $390-800 \mu \mathrm{m}$, zona compacta 20-35 $\mu \mathrm{m}$, zona subcompacta superioris 48-70 $\mu \mathrm{m}$, zona laxa intermedia 423-600 $\mu \mathrm{m}$, zona subcompacta inferioris 93-107 $\mu \mathrm{m}$, hymenium 58-65 $\mu \mathrm{m}$. Basidia 55-70 $\times 4.5-5 \mu \mathrm{m}$ and basidiospore cylindrical to allantoid, rarely observed 15-18 × 4.5-7 $\mu \mathrm{m}$.

Distribution - Cosmopolitan, In Brazil: states of AM, MT, PA, RS, SP.

Material examined - BRAZIL, Goiás State, City of Anápolis, Campus of the Universidade Estadual de Goiás, Trilha do Tatu Ecological Reserve, 28/09/2009 Xavier-Santos, S. (4313)-HUEG 8418; idem (4312)-HUEG 8423; idem 2001, Xavier-Santos, S. (3035)-HUEG 8378; City of Caldas

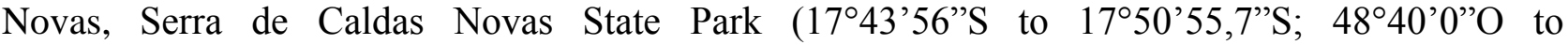
4842’57,6”O)01/05/2008 Xavier-Santos, S. (2850)-HUEG 8401, idem (2861)-HUEG 8398; City of Jataí, Açude Forest, 09/02/2011 Alvarenga, R.L.M. (77)-HUEG 8389; City of Pirenópolis, Dona Júlia's farm, 11/06/2009 Xavier-Santos, S. (3789)-HUEG 8452; City of Silvânia, Silvânia Forest Park (FLONA), 26/10/2007 Xavier-Santos, S. (807)-HUEG 8410; idem (838)-HUEG 8411; idem (888)-HUEG 8412; idem 26/06/2009 Xavier-Santos, S. (3874)-HUEG 8433; idem (3883)-HUEG 8413; idem (3855)-HUEG 8409; idem 22/10/2010 Alvarenga, R.L.M. (11)-HUEG 8481.

Notes - Collected from live trunks or trunks in decomposition, with or without direct exposure to sunlight. This species is distinguished from other species of the genus by exhibiting effused-reflexed basidioma with abhymenial surface in the substrate, in contrast to other species with lightly pedicellate concave basidioma. It can be easily confused with the species Trametes versicolor or Stereum ostrea (Looney et al. 2013), requiring analysis of microstructures as the presence of zone in cross-sectional and heterobasidia, for correct taxonomic determination. This is the first record of species occurrence for Goiás state.

Auricularia nigricans (Fr.) Birkebak, Looney \& Sánchez-García

Fig. 5

Description - Basidioma concave, $0.4-5.0 \mathrm{~cm}$, pedicellate to sessile, brittle when dry and cartillaginous when fresh. Abhymenial surface covered by wavy hairs, with narrow lumen. Hymenium vinous-black when dry. Margin generally more pilous, straight when young, becoming undulated when adult. Medulla present. Branched hyaline hyphae with slightly thick wall (1.5-2.5 $\mu \mathrm{m})$, immersed in a large amount of mucilage. Zona pilosa $600-700 \mu \mathrm{m}$, zona compacta $20-39$ $\mu \mathrm{m}$, zona subcompacta superioris 35-90 $\mu \mathrm{m}$, zona laxa superioris 73-200 $\mu \mathrm{m}$, medulla 40-230 $\mu \mathrm{m}$; zona laxa inferioris 36-340 $\mu \mathrm{m}$, zona subcompacta inferioris 47-170 $\mu \mathrm{m}$, hymenium 55-61 $\mu \mathrm{m}$. Basidia cylindrical 51-60 × 3.5-4.8 $\mu \mathrm{m}$, basidiospores hyaline, curved-cylindrical 11-15 $\times 4$ $6 \mu \mathrm{m}$. 

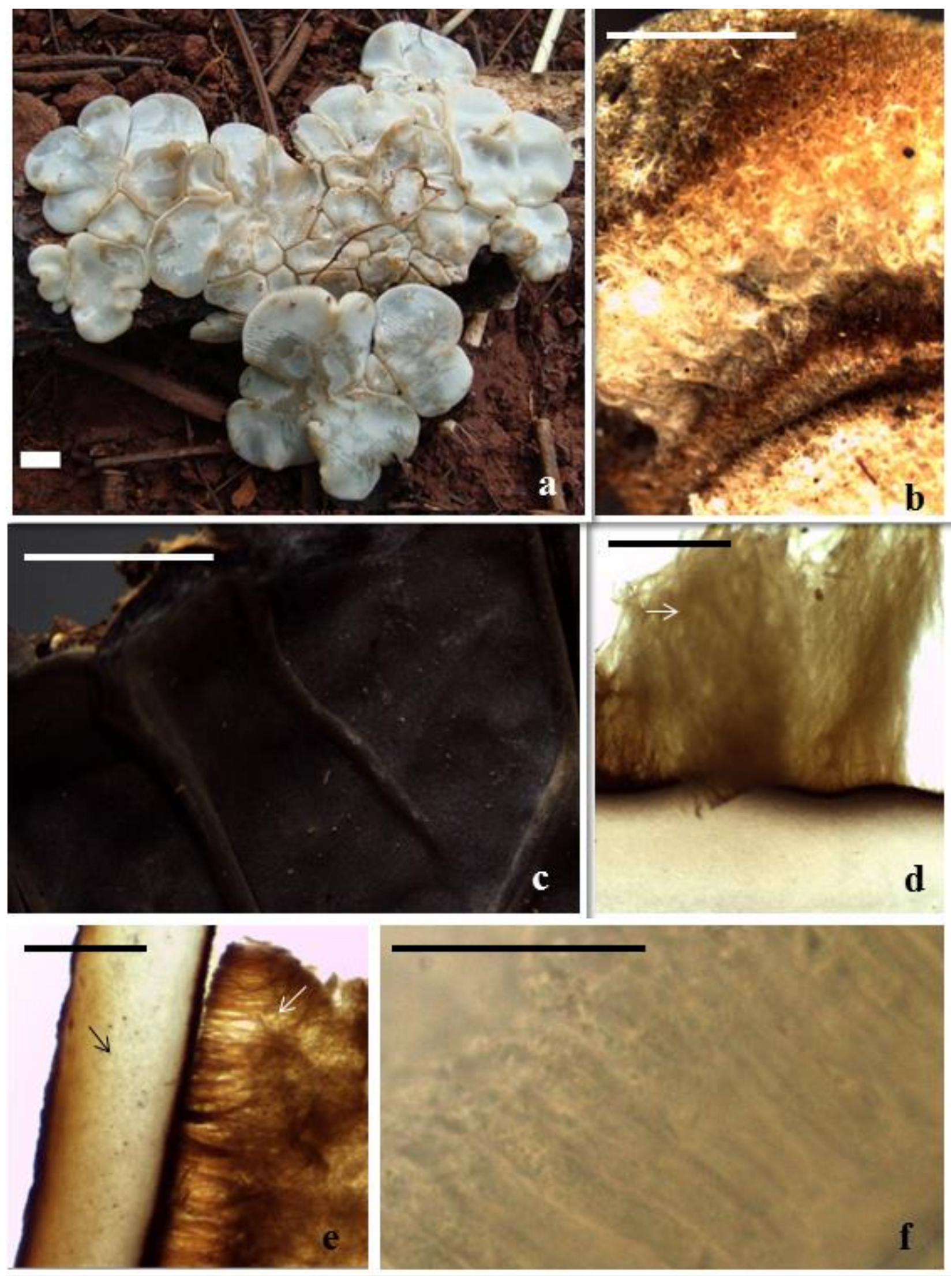

Fig. 4 - Auricularia mesenterica. a-Basidiomata on the substrate, hymenial surface; b-Pilous abhymenial surface of the dehydrated basidioma c-Hymenial surface of the dehydrated basidioma; d,e-Cross-section with context (black arrow) and abhymenial hairs (white arrow); f- Close-up of hymenial layer. Scale bars- a: $3 \mathrm{~cm}$; b-c: $2 \mathrm{~mm}$; d-e: $0.5 \mathrm{~mm}$; f: $20 \mu \mathrm{m}$ 

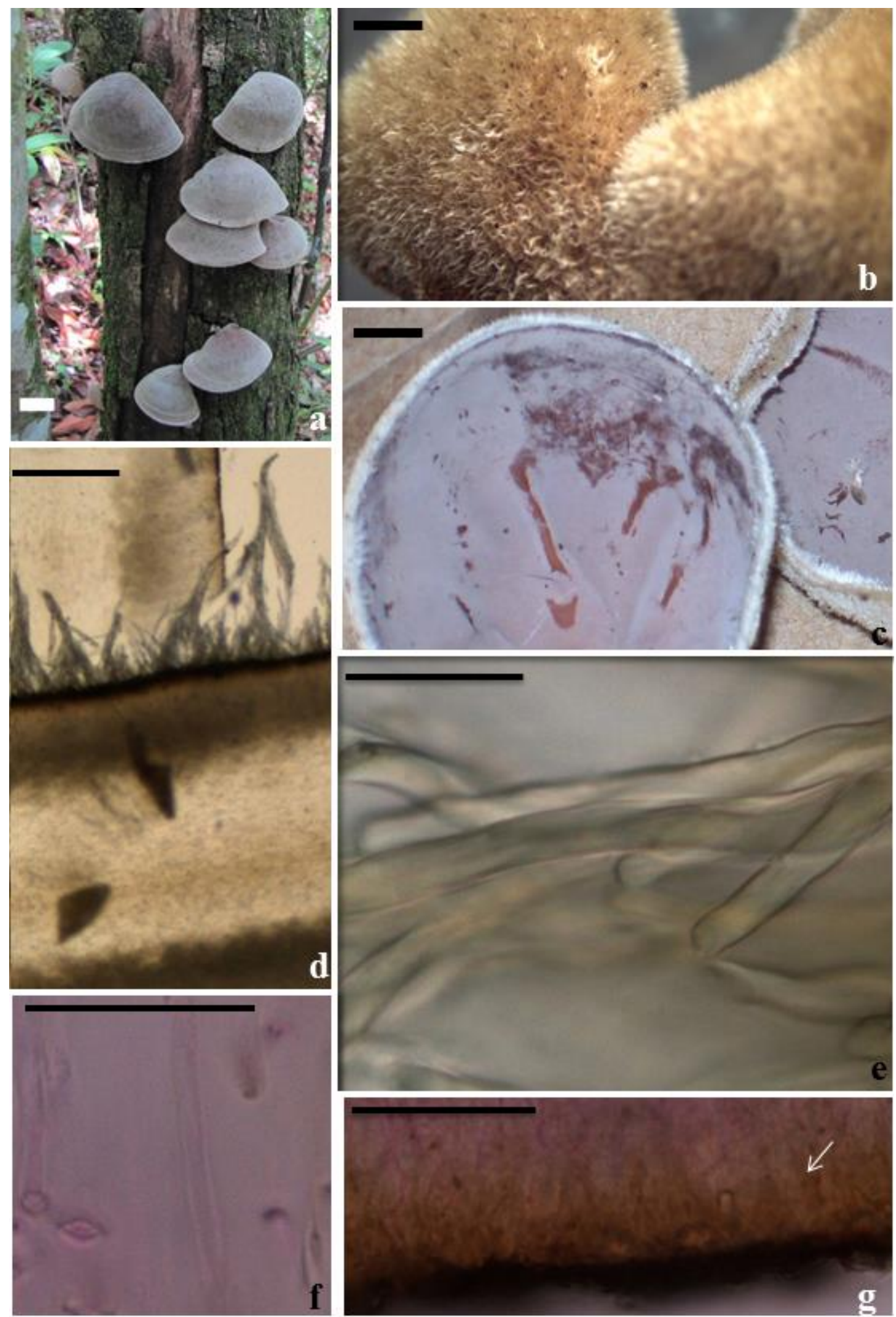

Fig. 5 - Auricularia nigricans. a-Basidiomata (abhymenial surface) on the substrate; b-Pilous abhymenial surface of the dehydrated basidioma; c-Hymenial surface of the fresh basidioma; dCross-section; e-Close-up of abhymenial hairs; f-hyphae of the medulla immersed in mucilage, stained with $2 \%$ Phloxine B, g-Hymenial layer, stained with $2 \%$ Phloxine B. Scale bars-a: $3 \mathrm{~cm}$; bc: $2 \mathrm{~mm}$; d: $0.5 \mathrm{~mm}$; e-g: $20 \mu \mathrm{m}$. 
Distribution - Cosmopolitan, in Brazil: states of AM, AP, BA, CE, DF, GO, MG, MT, PA, SC, SP, RJ, RO, RR, RS.

Material examined - BRAZIL, Federal District, Botanical Garden of Brasília, 01/12/2010. Alvarenga, R.L.M. (29)-HUEG 8395; Goiás, City of Anápolis, Campus of the Universidade Estadual de Goiás, Trilha do Tatu Ecological Reserve, 10/02/2009, Xavier-Santos, S. (3752)HUEG 8434; idem 28/09/2009, (4309)-HUEG 8453; idem (4310)-HUEG 8428; idem 08/02/2010, Xavier-Santos, S. (4281)-HUEG 8447; idem 08/10/2008, Xavier-Santos, S. (4043)-HUEG 8448; idem 2001, Xavier-Santos, S. (3072)-HUEG 8465; idem (3099)-HUEG 8393; idem (3053)-HUEG 8476; idem (3063)-HUEG 8386; idem (3046)-HUEG 8404; idem 10/11/2007, Faria, J.E.Q. \& Moreira, I.C. (204)-HUEG 8407; idem (213)-HUEG 8446; Ciliar Forest of Ribeirão das Antas, AmBev, Cebrasa Branch (16 $17^{\prime} 56.34$ 'S and 48 48'43.68'O), 10/05/2011, Xavier-Santos, S (4819)-HUEG 10270; idem 29/05/2011, Xavier-Santos, S (4618)-HUEG 10271; idem 07/07/2011, Xavier-Santos, S (4847)-HUEG 10272; City of Caldas Novas, Serra de Caldas Novas State Park $\left(17^{\circ} 42^{\prime} 53^{\prime \prime}\right.$ S and $\left.48^{\circ} 43^{\prime} 46^{\prime \prime} \mathrm{W}\right), 01 / 05 / 2008$, Xavier-Santos, S. (2806)-HUEG 8442; idem 02/11/2007, Xavier-Santos, S. (2138)-HUEG 8420; idem (17\%46'21''S and 48 39'07''W), 01/05/2007, Xavier-Santos, S. (2518)-HUEG 8396; idem (17\%42'53''S and 48 43'46''W), 01/05/2008, Xavier-Santos, S. (2771)-HUEG 8424; idem (2805)-HUEG 8445; idem (2882)-HUEG 8436; City of Goiânia, Campus II of the Universidade Federal de Goiás, Auguste Saint-Hilaire Forest (BASH), 22/02/2014 Naves, L.R.R. (144)-HUEG 10119; idem 30/05/2014 Naves, L.R.R. (333)-HUEG 10120; idem 27/06/2014 Naves, L.R.R. (364)-HUEG 10121; idem 27/06/2014 Naves, L.R.R. (366)-HUEG 10122; idem 27/06/2014 Naves, L.R.R. (369)-HUEG 10123; City of Jataí, Açude Forest, 09/02/2011, Alvarenga, R.L.M. (48)-HUEG 8380; idem (66)-HUEG 8390; idem (69)-HUEG 8391; idem (71)-HUEG 8379; idem (73)-HUEG 8489; idem (74)-HUEG 8490; idem (50)-HUEG 8375; City of Pirenópolis, Serra dos Pirineus State Park, 27/06/2008, Xavier-Santos, S. (1153)-HUEG 8432; idem (1162)-HUEG 8444; idem 11/06/2009, Xavier-Santos, S. (3803)-HUEG 8466; idem (3792)-HUEG 8405; City of Rio Quente, (1747'35''S and 4847'36' 'W), 28/03/2009, Xavier-Santos, S. (3627)-HUEG 8485; idem 29/03/2009, Xavier-Santos, S. (3658)-HUEG 8486;

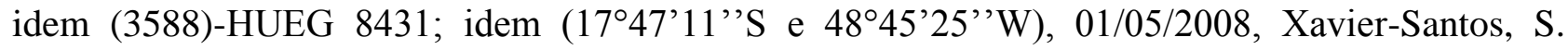
(2730)-HUEG 8439; idem (2685)-HUEG 8421; City of Silvânia, Silvânia Forest Park (FLONA), 26/10/2007, Xavier-Santos, S. (840)-HUEG 8430; idem (806)-HUEG 8417; idem (949)-HUEG 8443; idem (936)-HUEG 8422; idem 26/06/2009, Xavier-Santos, S. (3925)-HUEG 8449; idem (3864)-HUEG 8435; idem (3881)-HUEG 8397; idem (3859)-HUEG 8414; idem 22/10/2010, Xavier-Santos, S. (4465)-HUEG 8454; idem (4468)-HUEG 8456; idem Alvarenga, R.L.M. (13)HUEG 8474; idem (19)-HUEG 8480.

Notes - Collected from live trunks or trunks in decomposition, mainly in wet areas. A. nigricans is distinguished from others species of the genus by presenting the abhimenial surface densely tomentose with hairs exceeding $450 \mu \mathrm{m}$. The specie is the most commonly collected, compared with other species of the genus. It is an edible species and widely used in Chinese cuisine (Lowy 1971) and exhibiting medicinal value (Song \& Du 2011, Yu et al. 2014).

\section{Key to Auricularia species}

1. Pileate basidioma 2

1 '.Effused-reflexed basidioma. A. mesenterica

2. Basidioma with reticulate hymenial surface A. delicata

2'.Basidioma with smooth hymenial surface.

3. Abhymenial surface densely pilous (hairs $600-700 \mu \mathrm{m}$ long) A. nigricans

3 '.Abhymenial surface slightly pilous (hairs $40-100 \mu \mathrm{m}$ long). A. fuscosuccinea

\section{Acknowledgements}

To the Research Support Foundation of Goiás State (FAPEG) for the Masters scholarship awarded to the first author and for financial support (Processes no. 201210267001098 and AUXPE 2036/2013) 


\section{References}

Abrahão MC, Gugliotta AM, Bononi VLR. 2012 - Xylophilous Agaricomycetes (Basidiomycota) of the Brazilian Cerrado. CheckList, 8(5), 1102-1116.

Alvarenga RLM \& Xavier-Santos, S. 2015 - A checklist of Jelly Fungi (Agaricomycotina: Basidiomycota) recorded in Brazil. Mycotaxon, 130(3), in press.

Batista AC, Falção, RGS, Peres, GEP, Moura, NR. 1966 - Fungi Paraenses (Revisão da Coleção de Paul C. Hennings, do Museu Paraense Emílio Goeldi). Publicação do Instituto de Micologia. 506, 10-290.

Bulliard JBF. 1787 - Herbier de la France. Vol.7, Paris. 336p.

Drechsler-Santos, ER, Ryvarden, L, Bezerra, JL, Gibertoni, TB, Salvador-Montoya, CA, Cavalcanti, MAQ. 2013 - New records of Auriculariales, Hymenochaetales and Polyporales (Fungi:Agaricomycetes) for Caatinga Biome. CheckList, 9(4), 800-805.

Fidalgo MEPK, Hirata JM. 1979 - Etnomicologia Caiabi, Txicão e Txucarramãe. Rickia 9, 1-5.

Gibertoni TB, Drechsler-Santos ER. 2010 - Lignocellulolytic Agaricomycetes from the Brazilian Cerrado biome. Mycotaxon 111, 87-90.

Góes-Neto A. 1996 - Biodiversidade de Mixomicetos e Fungos Macroscópicos da Reserva Biológica de UNA e Áreas Adjacentes (Bahia, Brasil). Sitientibus 15, 91-108.

Kirk PM. 2015 - Species Fungorum (version Feb 2014). In: Species 2000 \& ITIS Catalogue of Life, 30th July 2015 (Roskov Y, Abucay L, Orrell T, Nicolson D, Kunze T, Flann C, Bailly N, Kirk P, Bourgoin T, DeWalt RE, Decock W, De Wever A, eds). Digital resource at www.catalogueoflife.org/col. Species 2000: Naturalis, Leiden, the Netherlands. http://www.catalogueoflife.org/col/search/all (accessed 05 April 2015).

Looney BP, Birkebak JM, Matheny B. 2013 - Systematics of the genus Auricularia with an emphasis on species from the southeastern United States. North American Fungi 8 (6), 1-25.

Lowy B. 1951 - A morphological basis for classifying the species of Auricularia. Mycologia 43, 351-358.

Lowy B. 1952 - The genus Auricularia. Mycologia 44, 656-692.

Lowy B. 1971 - Flora neotropica. Monograph no. 6. Tremellales. New York: Hafner Publishing Company. 153p.

Sobestiansky G. 2005 - Contribution to a Macromycete Survey of the States of Rio Grande do Sul and Santa Catarina in Brazil. Brazilian Archives of Biology and Technology 48(3), 437457.

Song G, Du Q. 2011 - Structure characterization and antitumor activity of an $\alpha \beta$-glucan polysaccharide from Auricularia polytricha. Food Research International 45, 381-387.

Trierveiler-Pereira L, Baltazar JM, Loguercio-Leite C. 2009 - Santa Catarina Island mangroves 4 Xylophilous basidiomycetes. Mycotaxon 109, 107-110.

Vasco-Palacios AM, Suaza SC, Castaño-Betancur M, Franco-Molano AE. 2008 - Conocimento etnoecólogico de los hongos entre los indígenas Uitoto, Muinane y Andoke de la Amazonía Colombiana. Acta Amazonica 38(1), 17-30.

Yu J, Sun R, Zhao Z, Wang Y. 2014 - Auricularia polytricha polysaccharides induce cell cycle arrest and apoptosis in human lug cancer A549. International Journal of Biological Macromolecules 68, 67-71. 